\title{
THE EFFECT OF SWEATING ON THE PROTHROMBIN TIMES OF BLOOD
}

\author{
BY \\ E. F. ST. J. LYBURN \\ From the Royal Tunbridge Wells Spa, Tunbridge Wells
}

(RECEIVED FOR PUBLICATION OCTOBER 9, 1957)

Prothrombin times have been estimated in man before and after sweating, showing that prothrombin times are increased after exposure to high environmental temperatures over a period of 40 minutes.

\section{Methods}

The process used to induce sweating is described by Lyburn (1956). Two millilitres of blood were taken from antecubital veins before and after sweating and put into bottles containing $0.2 \mathrm{ml}$. of $1.34 \%$ sodium oxalate and sent to a laboratory within an hour for estimation of the prothrombin times. The method used was a modification of Quick's method, using thrombokinase "geigy" and $0.18 \%$ calcium chloride. The normal by this method is 15 to 16 seconds.

Subjects on anticoagulant therapy were given "marcoumar," $3 \mathrm{mg}$. b.d. for two days, and thereafter $1.5 \mathrm{mg}$. for two or three days until the prothrombin time reached 30 or 40 seconds. Thereafter they were maintained on $1.5 \mathrm{mg}$. five times a week.

\section{Results}

Comparison of the prothrombin times before and after sweating shows a significant rise over a period of 40 minutes. In Table $I$ the increase in prothrombin times varied from 22 to 281 seconds, where treatment with anticoagulants and sweating was combined. The average increase in prothrombin times in these subjects was 93 seconds, but none of the subjects showed any evidence of bleeding. Table II shows five subjects in which the plasma failed to coagulate and three subjects in which the prothrombin times increased an average of 10 seconds.

\section{Discussion}

The increase of prothrombin times after sweating is significant, and Tawfic (1955) observed that anticoagulant therapy has to be more carefully watched in tropical climates. Doan (1953) observed a rise in prothrombin times in a subject who died following hyperpyrexial treatment. The efficiency of the factor V-factor VII-prothrombin system is affected by anticoagulants, and as shown in Table $I$ this prothrombin system may also be affected by sweating and high environmental temperatures. It has been reported that prothrombin times vary over a period of days after anticoagulant therapy (Matthews, Meynell, Parsons, Warburton, and Waterhouse, 1955), but there has been no

\section{TABLE I}

PROTHROMBIN TIMES AFTER COMBINED ANTICOAGULANT AND WET THERMAL TREATMENT

\begin{tabular}{c|c|c|c|c|c}
\hline Date & Age & $\begin{array}{c}\text { Sex and } \\
\text { Diagnosis }\end{array}$ & $\begin{array}{c}\text { Prothrombin } \\
\text { Time before } \\
\text { Treatment } \\
\text { (sec.) }\end{array}$ & $\begin{array}{c}\text { Prothrombin } \\
\text { Time after } \\
\text { Treatment } \\
\text { (sec.) }\end{array}$ & $\begin{array}{c}\text { Average } \\
\text { Normal } \\
\text { (sec.) }\end{array}$ \\
\hline $4 / 8 / 54$ & 70 & $\begin{array}{c}\text { F. Coronary } \\
\text { thrombo- } \\
\text { sis }\end{array}$ & 36 & 59 & 17 \\
$7 / 1 / 55$ & 66 & $\begin{array}{c}\text { M. Retinal } \\
\text { embolism }\end{array}$ & 27 & 58 & 17 \\
$17 / 5 / 54$ & 56 & F. Muscular \\
degenera- \\
tion
\end{tabular}

TABLE II

PROTHROMBIN TIMES AFTER SWEATING

\begin{tabular}{|c|c|c|c|c|c|}
\hline Date & Age & $\begin{array}{l}\text { Sex and } \\
\text { Diagnosis }\end{array}$ & $\begin{array}{l}\text { Prothrombin } \\
\text { Time before } \\
\text { Treatment } \\
\text { (sec.) }\end{array}$ & $\begin{array}{c}\text { Prothrombin } \\
\text { Time after } \\
\text { Treatment } \\
(\mathrm{sec} .)\end{array}$ & $\begin{array}{c}\text { Average } \\
\text { Normal } \\
\text { (sec.) }\end{array}$ \\
\hline $20 / 5 / 55$ & 56 & $\begin{array}{l}\text { M. Coronary } \\
\text { thrombo- } \\
\text { sis }\end{array}$ & 17 & $\begin{array}{l}\text { Failed to } \\
\text { coagulate }\end{array}$ & 17 \\
\hline $\begin{array}{l}20 / 12 / 54 \\
22 / 12 / 54\end{array}$ & $\begin{array}{l}70 \\
52\end{array}$ & $\begin{array}{l}\text { M. Angina .. } \\
\text { M. Parkin- }\end{array}$ & 16 & , & 17 \\
\hline & & $\begin{array}{l}\text { M. Parkin- } \\
\text { son's } \\
\text { disease }\end{array}$ & & ", & \\
\hline $20 / 11 / 54$ & 72 & $\begin{array}{l}\text { M. Cardiac } \\
\text { irregular- } \\
\text { ity }\end{array}$ & 16 & , & 17 \\
\hline $6 / 5 / 56$ & 73 & F. Auricular & 17 & ", & 17 \\
\hline $\begin{array}{c}20 / 12 / 54 \\
5 / 5 / 55\end{array}$ & $\begin{array}{l}70 \\
56\end{array}$ & $\begin{array}{c}\text { F. Angina } \\
\text { M. Cerebrai } \\
\text { thrombo- } \\
\text { sis }\end{array}$ & $\begin{array}{l}13 \\
13\end{array}$ & $\begin{array}{l}23 \\
24\end{array}$ & $\begin{array}{l}17 \\
17\end{array}$ \\
\hline $20 / 12 / 54$ & 70 & 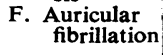 & 13 & 23 & 17 \\
\hline
\end{tabular}


report of prothrombin times varying in man when exposed to constant or varying environmental temperatures.

\section{Summary}

Prothrombin times have been recorded before and after sweating with and without the use of anticoagulants in a number of subjects suffering from thrombotic manifestations. The results have shown a significant increase in prothrombin times following sweating with and without anticoagulants.

The average rise in prothrombin times following treatment combined with anticoagulant therapy was 93 seconds and without anticoagulants the average rise was 10 seconds.

In five subjects (treated without anticoagulants) blood failed to coagulate after sweating.

Bleeding did not occur in any of these subjects.

\section{REFERENCES}

Doan, O. (1953). Personal communication from Roche Ltd., Chemists.

Lyburn, E. F. St. John (1956). J. Physiol. (Lond.), 134, 207.

Matthews, H. L., Meynell, M. J., Parsons, C. G., Warburton, E. G., and Waterhouse, J. A. H. (1955). Brit. med. J., 2, 947.

Tawfic, A. (1955). Lancet, 2, 984. 